\section{Performance of Low-maintenance Turfgrass Mixtures and Blends}

\author{
Daniel R. Miller ${ }^{1,4,8}$, Robert J. Mugaas ${ }^{2,5}$, Mary H. Meyer ${ }^{3,6}$, \\ and Eric Watkins ${ }^{3,7}$
}

AdDitional INDEX wORDs. fine fescue, low-fertility soils, minimal mowing, native grasses, no-mow, tall fescue

SumMary. Several studies have been conducted on low-maintenance turfgrass species; however, relatively few have evaluated mixtures or blends. The objective of this study was to evaluate low-maintenance turfgrass mixtures or blends for turf quality under minimal input conditions. Eight turfgrass mixtures or blends were planted in 2009 at the University of Minnesota Landscape Arboretum (Chaska, MN) on a low-fertility soil to assess their adaptability to low-input conditions (minimal water and fertilizer and no pesticides after establishment). The year after establishment, plots were divided into no-mow and minimal mow treatments. Plots were evaluated for establishment in 2009 and overall quality and percent weed cover in 2009,2010 , and 2011. Native grass mixtures established slowly with greater weed encroachment, but over time resulted in high-quality ratings. Under minimal mowing, the Tall Fescue Blend [tall fescue (Festuca arundinacea)] performed the best for quality, while three fine fescue (Festuca sp.) mixtures and the Tall Fescue/ Kentucky Bluegrass Mixture [tall fescue + kentucky bluegrass (Poa pratensis)] also had acceptable quality ratings. The Kentucky Bluegrass Blend (kentucky bluegrass) was less competitive with weeds and had unacceptable quality ratings. Under nomow conditions, the native grass mixtures and the Tall Fescue Blend had the highest overall quality ratings.

$\mathrm{L}$ ow-maintenance turfgrass species that provide acceptable quality with reduced inputs and less mowing are of interest to homeowners and turf managers looking to reduce management costs and environmental impacts. In a recent study, Watkins et al. (2011) evaluated 12 grass species under mowed and unmowed conditions in eight U.S. states of the northcentral region and found that hard fescue (Festuca tracyphylla), tall fescue, and sheep fescue (Festuca ovina) performed well at most locations. Several native grass species also show potential for low-maintenance turfgrass areas. Mintenko et al. (2002) evaluated 12 species of native grasses adapted to the northern Great Plains for 4 years at Winnipeg and Carmen, MB, Canada, and found blue grama (Bouteloua gracilis) and prairie junegrass (Koeleria

\footnotetext{
${ }^{1}$ University of Minnesota Landscape Arboretum, Chaska, MN 55318

${ }^{2}$ University of Minnesota, Rosemount, MN 55068

${ }^{3}$ Department of Horticultural Science, University of Minnesota, St. Paul, MN 55108

${ }^{4}$ Scientist

${ }^{5}$ Extension Professor Emeritus

${ }^{6}$ Professor

${ }^{7}$ Associate Professor

${ }^{8}$ Corresponding author. E-mail: mille414@umn.edu.
}

macrantha) had potential for use as low-maintenance turf. Mixtures of turfgrasses provide genetic diversity that can potentially decrease susceptibility to environmental and pest pressures (Beard, 1973); however, relatively few low-maintenance turf studies have been conducted to evaluate mixtures or blends (Dernoeden et al., 1998; McKernan et al., 2001; Meyer and Pedersen, 1999). The objective of this project was to evaluate commercially available, low-maintenance grass mixtures or blends for turf quality under minimal input conditions.

\section{Materials and methods}

The study was located at the University of Minnesota Landscape Arboretum and consisted of eight lowmaintenance turfgrass mixtures and blends (Table 1 ) planted in $10-\mathrm{ft}^{2}$ plots in a randomized complete block design with three replications. Soil at this site was composed of a lowfertility, construction fill gravelly clay subsoil with $1.7 \%$ organic matter; therefore, a 2 -inch layer of yard waste compost was incorporated with a rotary tiller before seeding. Plots were seeded on 7 May 2009 and covered with Futerra erosion-control blankets (Profile Products, Buffalo Grove, IL). Plots were watered regularly during establishment and fertilized twice (40 and $109 \mathrm{~d}$ after seeding) at 1.0 $\mathrm{lb} / 1000 \mathrm{ft}^{2}$ nitrogen $(\mathrm{N})$ per application. Broadleaf weeds were controlled with 2,4-D amine (AgriSolutions, Brighton, IL) on 2 July 2009 and 2,4-D amine + triclopyr (Nufarm Americas, Burr Ridge, IL) on 23 Sept. 2009. All plots were mowed at 3 inches during 2009. Establishment data were collected three times in the 2 months following seeding. In 2010 and 2011, all plots were mowed once in the spring (early May) at 3 inches and then half of each plot was not mowed while the other half of the plot was mowed to 3 inches as needed (three to four times per year) to maintain a height of cut acceptable for a home lawn or a large low-maintenance commercial lawn. Irrigation and broadleaf weed control were not applied in 2010 or 2011 , and fertilization was reduced to $1.0 \mathrm{lb} / 1000 \mathrm{ft}^{2} \mathrm{~N}$ applied once annually in Fall 2010 and 2011. Drought conditions were prevalent in 201 1; precipitation from Aug. to Dec. 2011 was 4.6 inches; the average for this period is 12.4 inches (Boulay, 2013). Data were collected visually throughout the growing season for turfgrass quality $(1=$ poor, $5=$ acceptable, $10=$ excellent ) and percent weed cover in 2009, 2010, and 2011. For mowed plots, turfgrass quality components included color, density, uniformity, and lack of weeds and diseases. For unmowed plots, quality characteristics included uniformity, seedhead abundance, lack of lodging, and lack of weeds and diseases. Data were analyzed with a one-way analysis of variance using SPSS (version 17; IBM Corp., Armonk, NY) and means were separated using the WallerDuncan $t$ test $(P<0.05)$. Minimal

\begin{tabular}{llll}
\hline $\begin{array}{l}\text { Units } \\
\begin{array}{l}\text { To convert U.S. to SI, } \\
\text { multiply by }\end{array}\end{array}$ & U.S. unit & SI unit & $\begin{array}{l}\text { To convert SI to U.S., } \\
\text { multiply by }\end{array}$ \\
\hline 0.0929 & $\mathrm{ft}^{2}$ & $\mathrm{~m}^{2}$ & 10.7639 \\
2.54 & inch $(\mathrm{es})$ & $\mathrm{cm}$ & 0.3937 \\
48.8243 & $\mathrm{lb} / 1000 \mathrm{ft}^{2}$ & $\mathrm{~kg} \cdot \mathrm{ha}^{-1}$ & 0.0205
\end{tabular}


Table 1. Composition of low-input turfgrass mixtures and blends evaluated at the Minnesota Landscape Arboretum (Chaska, MN) for performance in both mowed and unmowed plots in 2009, 2010, and 2011.

Mixture or blend

Fine Fescue Mixture no. 1

Fine Fescue Mixture no. 2

Fine Fescue Mixture no. 3

Tall Fescue/Kentucky Bluegrass Mixture

Tall Fescue Blend

Kentucky Bluegrass Blend

Native Mixture no. 1

Native Mixture no. 2
Composition (\% by wt) $)^{\mathrm{z}}$

25\% 'Azure' sheep fescue (Festuca ovina), 25\% 'Victory II' chewings fescue (Festuca rubra var. fallax), 12.5\% 'Spartan II' hard fescue (Festuca tracyphylla), 12.5\% 'Heron' hard fescue, 13\% 'Lifine' slender creeping red fescue (F. rubra var. littorlis), 12\% VNS strong creeping red fescue (F. rubra)

$10 \%$ VNS blue fescue (Festuca glauca), 20\% VNS chewings fescue, 15\% 'Chariot' hard fescue, 10\% 'Heron' hard fescue, 45\% 'Jasper II', 'Longfellow', and 'Dawson' creeping red fescue

$25 \%$ VNS sheep fescue, 25\% 'Intrigue' chewings fescue, 25\% 'Firefly' hard fescue, $25 \%$ 'Boreal' strong creeping red fescue

30\% 'Raptor' tall fescue (Festuca arundinacea), 29\% 'Spyder' tall fescue, 25\%

'Titanium' tall fescue, 15\% 'Cadet' kentucky bluegrass (Poa pratensis)

$30 \%$ 'Greenskeeper' tall fescue, 30\% 'Coyote II' tall fescue, 20\% 'Tarheel II' tall fescue, $20 \%$ 'Fidelity' tall fescue

33\% 'Rambo' kentucky bluegrass, 33\% 'Rugby II' kentucky bluegrass, 33\%

'Bluechip' kentucky bluegrass

53\% little bluestem (Schizachyrium scoparius), 32\% side-oats grama (Bouteloua curtipendula), 10\% blue grama (Boutelona gracilis), 3\% prairie junegrass (Koeleria macrantha), 1\% poverty oat grass (Danthonia spicata), 1\% kalm's brome (Bromus kalmia)

35\% side-oats grama, 17\% blue grama, 39\% buffalograss (Bouteloua dactyloides), $9 \%$ prairie junegrass

${ }^{2}$ Variety not stated.

mow and no-mow plots were analyzed separately.

\section{Results}

Performance during the year OF ESTABLISHMENT. Significant differences in percent cover in 2009 can be attributed to the two native grass mixtures' inability to cover the soil during establishment (Table 2). Slow establishment for Native Mixture no. 1 also resulted in higher weed counts than the fine and tall fescue mixtures (Table 3). During establishment, prevalent weeds were yellow foxtail (Setaria glauca), ragweed (Ambrosia artemesifolia), black medic (Medicago lupilina), lambsquarter (Chenopodium album), crabgrass (Digitaria sanguinalis), and redroot pigweed (Amaranthus retroflexus). Differences for quality in 2009 can be attributed to lower ratings for Native Mixture no. 1 relative to the Tall Fescue Blend or the fine fescue mixtures.

Performance under minimal MOWING CONDITIONs. After 3 years, the Tall Fescue Blend had the highest quality ratings and the Kentucky Bluegrass Blend had lower quality ratings than the other mixtures under minimal mowing conditions (Table 3 ). The fine fescue mixtures were adversely affected by leaf spot (Bipolaris sorokiniana) and melting out (Drechslera poae)
Table 2. Percent cover at 24,41 , and $56 \mathrm{~d}$ after seeding (DAS) for eight lowmaintenance turf mixtures/blends evaluated at the Minnesota Landscape Arboretum (Chaska, MN) in 2009.

\begin{tabular}{lccc}
\hline & \multicolumn{3}{c}{ Turfgrass cover (\%) } \\
\cline { 2 - 4 } Mixture & 24 DAS & 41 DAS & 56 DAS \\
\hline Tall Fescue Blend & $38.3 \mathrm{a}^{\mathrm{z}}$ & $65.0 \mathrm{a}$ & $95.0 \mathrm{a}$ \\
Fine Fescue Mixture no. 3 & $36.7 \mathrm{a}$ & $53.3 \mathrm{bc}$ & $95.0 \mathrm{a}$ \\
Fine Fescue Mixture no. 1 & $38.3 \mathrm{a}$ & $60.0 \mathrm{bc}$ & $88.3 \mathrm{ab}$ \\
Tall Fescue/Kentucky Bluegrass Mixture & $30.0 \mathrm{a}$ & $58.3 \mathrm{bc}$ & $81.7 \mathrm{ab}$ \\
Fine Fescue Mixture no. 2 & $28.3 \mathrm{a}$ & $50.0 \mathrm{bc}$ & $83.3 \mathrm{ab}$ \\
Kentucky Bluegrass Blend & $23.3 \mathrm{a}$ & $43.3 \mathrm{~b}$ & $75.0 \mathrm{bc}$ \\
Native Mixture no. 2 & $8.3 \mathrm{a}$ & $15.0 \mathrm{c}$ & $63.3 \mathrm{c}$ \\
Native Mixture no. 1 & $8.3 \mathrm{a}$ & $11.7 \mathrm{c}$ & $46.7 \mathrm{~d}$ \\
\hline
\end{tabular}

${ }^{\mathrm{z}}$ Means followed by the same letter are not significantly different by Waller-Duncan $t$ test $(P<0.05)$.

Table 3. Turfgrass quality ratings and percent weed cover for eight lowmaintenance turf mixtures/blends evaluated at the Minnesota Landscape Arboretum (Chaska, MN) in 2009, 2010, and 2011 under minimal mowing conditions.

\begin{tabular}{|c|c|c|c|c|c|c|}
\hline \multirow[b]{2}{*}{ Mixture } & \multicolumn{3}{|c|}{ Quality $(1-10 \text { scale })^{\mathrm{z}}$} & \multicolumn{3}{|c|}{ Weeds (\%) } \\
\hline & 2009 & 2010 & 2011 & 2009 & 2010 & 2011 \\
\hline Tall Fescue Blend & $6.0 \mathrm{a}^{\mathrm{y}}$ & $6.7 \mathrm{a}$ & $7.4 \mathrm{a}$ & $2.8 \mathrm{~b}$ & $4.2 \mathrm{a}$ & $5.0 \mathrm{~b}$ \\
\hline Native Mixture no. 1 & $3.4 \mathrm{~b}$ & $5.4 \mathrm{a}$ & $7.3 \mathrm{a}$ & $25.0 \mathrm{a}$ & $2.5 \mathrm{a}$ & $11.7 \mathrm{~b}$ \\
\hline Native Mixture no. 2 & $4.5 \mathrm{ab}$ & $5.9 \mathrm{a}$ & $7.1 \mathrm{a}$ & $17.5 \mathrm{ab}$ & $2.5 \mathrm{a}$ & $8.3 \mathrm{~b}$ \\
\hline Fine Fescue Mixture no. 1 & $5.4 \mathrm{a}$ & $5.9 \mathrm{a}$ & $6.1 \mathrm{ab}$ & $6.0 \mathrm{~b}$ & $1.7 \mathrm{a}$ & $8.3 \mathrm{~b}$ \\
\hline Fine Fescue Mixture no. 3 & $6.0 \mathrm{a}$ & $5.7 \mathrm{a}$ & $5.9 \mathrm{ab}$ & $3.8 \mathrm{~b}$ & $3.3 \mathrm{a}$ & $3.3 \mathrm{~b}$ \\
\hline Fine Fescue Mixture no. 2 & $5.6 \mathrm{a}$ & $5.7 \mathrm{a}$ & $5.8 \mathrm{ab}$ & $4.3 \mathrm{~b}$ & $2.5 \mathrm{a}$ & $1.7 \mathrm{~b}$ \\
\hline $\begin{array}{c}\text { Tall Fescue/Kentucky } \\
\text { Bluegrass Mixture }\end{array}$ & $5.2 \mathrm{ab}$ & $5.5 \mathrm{a}$ & $5.6 \mathrm{ab}$ & $3.7 \mathrm{~b}$ & $14.2 \mathrm{a}$ & $30.0 \mathrm{ab}$ \\
\hline Kentucky Bluegrass Blend & $4.4 \mathrm{ab}$ & $4.7 \mathrm{a}$ & $3.9 \mathrm{~b}$ & $8.7 \mathrm{ab}$ & $8.3 \mathrm{a}$ & $60.0 \mathrm{a}$ \\
\hline
\end{tabular}

${ }^{\mathrm{z}} 1$ = poor, 5 = acceptable, $10=$ excellent.

${ }^{y}$ Means within columns followed by the same letter are not significantly different by Waller-Duncan $t$ test $(P<0.05)$. 
diseases in 2010 and 2011 , but this did not significantly affect overall quality ratings. The two native mixtures had the most improvement from 2009 to 2011. Although slow to establish and initially weedy, by the end of the experiment, the native mixtures outcompeted weeds and had high-quality ratings. By 2011, the Kentucky Bluegrass Blend had significantly more weeds than the other mixtures except for the Tall Fescue/Kentucky Bluegrass Mixture. In 2010 and 2011, the most common weeds were birdsfoot trefoil (Lotus corniculatus), tall fescue, and crabgrass.

Performance under no-mow CONDITIONS. By 2011 , the native mixtures and the Tall Fescue Blend had significantly higher quality ratings than other entries under no-mow conditions (Table 4). The higher quality ratings for the native grasses can be attributed to their unique seed heads and stem colors and their upright form with minimal lodging. The Kentucky Bluegrass Blend had significantly lower quality than any other mixture or blend in 2010, along with significantly higher weed percentage in 2011. This blend was not competitive against weeds under no-mow conditions. No mowing favored native grasses and appeared to be a severe disadvantage for kentucky bluegrass.

\section{Discussion}

The low-fertility soil along with drought conditions made this a difficult site, but ideal conditions during establishment allowed for a successful trial. With the exception of the Kentucky Bluegrass Blend, the overall quality of all the mixtures and blends tested was acceptable for the lowmaintenance conditions. The three fine fescue mixtures were affected by turf diseases but still had acceptable quality; they were particularly well suited to the minimal mowing conditions, the low-fertility soil, and the drought conditions. Find fescue mixtures also performed well in studies by Meyer and Pedersen (1999) and McKernan et al. (2001). Both tall fescue mixtures also performed well

Table 4. Turfgrass quality ratings and percent weed cover for eight lowmaintenance turf mixtures/blends evaluated at the Minnesota Landscape Arboretum (Chaska, MN) in 2010 and 2011 under no-mow conditions.

\begin{tabular}{|c|c|c|c|c|}
\hline \multirow[b]{2}{*}{ Mixture } & \multicolumn{2}{|c|}{ Quality $(1-10 \text { scale })^{\mathrm{z}}$} & \multicolumn{2}{|c|}{ Weeds (\%) } \\
\hline & 2010 & 2011 & 2010 & 2011 \\
\hline Native Mixture no. 1 & $6.2 \mathrm{a}^{\mathrm{y}}$ & $7.5 \mathrm{a}$ & $3.3 \mathrm{ab}$ & $6.7 \mathrm{~b}$ \\
\hline Native Mixture no. 2 & $6.1 \mathrm{a}$ & $7.4 \mathrm{a}$ & $4.2 \mathrm{ab}$ & $0.0 \mathrm{~b}$ \\
\hline Tall Fescue Blend & $6.1 \mathrm{a}$ & $7.1 \mathrm{a}$ & $0.8 \mathrm{~b}$ & $8.3 \mathrm{~b}$ \\
\hline Fine Fescue Mixture no. 1 & $6.6 \mathrm{a}$ & $5.9 \mathrm{~b}$ & $3.3 \mathrm{ab}$ & $6.7 \mathrm{~b}$ \\
\hline Fine fescue Mixture no. 3 & $6.0 \mathrm{a}$ & $5.8 \mathrm{~b}$ & $2.5 \mathrm{ab}$ & $5.0 \mathrm{~b}$ \\
\hline Tall Fescue/Kentucky Bluegrass Mixture & $5.9 \mathrm{a}$ & $5.4 \mathrm{~b}$ & $5.8 \mathrm{ab}$ & $8.3 \mathrm{~b}$ \\
\hline Fine Fescue Mixture no. 2 & $5.9 \mathrm{a}$ & $5.2 \mathrm{bc}$ & $3.3 \mathrm{ab}$ & $16.7 \mathrm{~b}$ \\
\hline Kentucky Bluegrass Blend & $4.9 \mathrm{~b}$ & $4.3 \mathrm{c}$ & $7.5 \mathrm{a}$ & $46.7 \mathrm{a}$ \\
\hline
\end{tabular}

${ }^{\mathrm{z}} 1$ = poor, 5 = acceptable, $10=$ excellent.

${ }^{y}$ Means within columns followed by the same letter are not significantly different by Waller-Duncan $t$ test $(P<0.05)$.

under these conditions, but the Tall Fescue Blend out-performed the Tall Fescue/Kentucky Bluegrass Mixture in both minimal and no-mow conditions. The Tall Fescue Blend was also particularly well suited to low-fertility soil conditions and was tolerant to drought conditions. Although native mixtures were slow to establish and weedy the first year, by the third year they out-competed weeds and resulted in high-quality ratings. Native warmseason grass foliage color and interesting seed heads made them well suited for no-mow conditions; however, many native grass species have not been improved to the point of providing acceptable quality under minimal mowing low-maintenance conditions.

The results of this study demonstrate that several mixtures and blends of nontraditional turfgrass species have good potential for broader use in low-maintenance conditions in the upper Midwestern United States. Homeowners and turfgrass managers looking for alternative low-maintenance grasses should consider tall fescue, fine fescue, or native warm-season grass mixtures and blends. These species can be adapted to many areas of the landscape including difficult-tomow areas such as berms and hillsides, edges in low-traffic areas, golf course out-of-play areas, lakeshore properties, and nonirrigated areas. Selecting mixtures is important, allowing for species to self-select for variable soil fertility, moisture levels, and weed pressure.

\section{Literature cited}

Beard, J.B. 1973. Turfgrass science and culture. Prentice-Hall, Englewood Cliffs, NJ.

Boulay, P.J. 2013. Minnesota climatology working group. '211465 Chaska station' climate data retrieval. 5 Apr. 2013. <http://climate.umn.edu/HID radius/ radius.asp $>$.

Dernoeden, P., M. Fidanza, and J. Krouse. 1998. Low maintenance performance of five Festuca species in monostands and mixtures. Crop Sci. 38:434-439.

Meyer, M.H. and B. Pedersen. 1999. Low maintenance alternative turfgrass trials. J. Turfgrass Mgt. 3:49-57.

McKernan, D.K., J.B. Ross, and D.K. Tompkins. 2001. Evaluation of grasses grown under low maintenance conditions. Intl. Turfgrass Soc. Res. J. 9:25-32.

Mintenko, A., S. Smith, and D. Cattani. 2002. Turfgrass evaluation of native grasses for the northern Great Plains region. Crop Sci. 42:2018-2024.

Watkins, E., S. Fei, D. Gardner, J. Stier, S. Bughrara, D. Li, C. Bigelow, L. Schliecher, B. Horgan, and K. Diesburg. 2011. Low-input turfgrass species for the north central United States. Online. Appl. Turfgrass Sci. doi:10.1094/ATS-20110126-02-RS. 